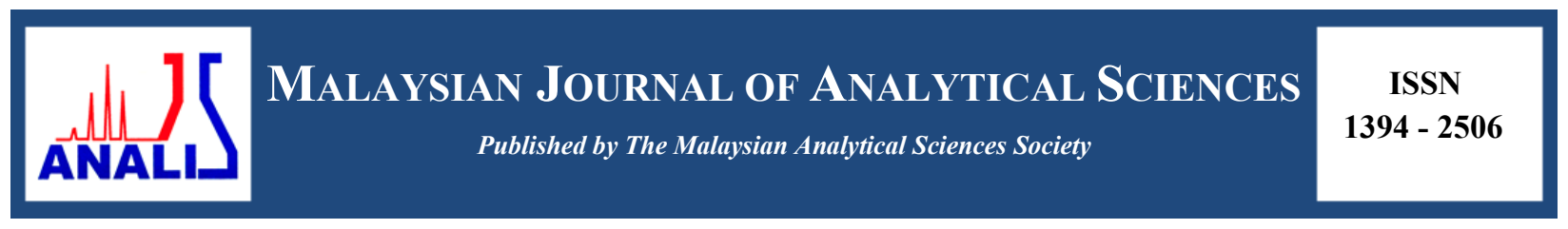

\title{
METALS CONTAMINATION USING Polymesoda expansa (MARSH CLAM) AS BIO-INDICATOR IN KELANTAN RIVER, MALAYSIA
}

\section{(Pencemaran Logam di Sungai Kelantan, Malaysia Menggunakan Polymesoda expansa (Lokan) Sebagai Penunjuk Biologi)}

\author{
Ong Meng Chuan ${ }^{1 *}$, Muhammad Izzat Kamaruzaman ${ }^{1}$, Yong Jaw Chuen ${ }^{1}$, Kamaruzzaman Bin Yunus ${ }^{2}$, \\ Joseph Bidai ${ }^{3}$ \\ ${ }^{1}$ School of Marine and Environmental Sciences, \\ Universiti Malaysia Terengganu, 21030 Kuala Terengganu, Malaysia \\ ${ }^{2}$ Department of Marine Science, Kulliyyah of Science, \\ International Islamic Universiti Malaysia, Bandar Indera Mahkota, 25200 Kuantan, Pahang, Malaysia \\ ${ }^{3}$ Institute of Oceanography and Environment, \\ Universiti Malaysia Terengganu, 21030 Kuala Terengganu, Malaysia \\ *Corresponding author: ong@umt.edu.my
}

Received: 7 August 2016; Accepted: 13 April 2017

\begin{abstract}
Bivalve, such as marsh clam (Polymesoda expansa) feed by filtering most of the suspended particle in water that surrounding them. Lots of elements being trap into their body via this feeding habit including pollutant such as trace metals. Unfortunately, these marsh clams were taken directly by human as their daily diet. Due to its ability to filter water, marsh clam was used to monitor the level of trace metals in aquatic system in significant place such as industrial area. Therefore, this study was carried out at Kelantan River near to the industrial area in Pengkalan Chepa, Kelantan, Malaysia. A total of 80 marsh clams were collected from 4 different sites to represent a different environmental condition. The in-toto of the marsh clam were dissected and digest with suprapur nitric acid by using Teflon Bomb method. Six metals were determined by using Inductively Coupled Plasma Mass Spectrometry including chromium, iron, copper, cadmium, lead and zinc. The highest mean concentration of all metals studied (Cr $45.03 \mu \mathrm{g} / \mathrm{g}$ dry weight; Fe $1.28 \mu \mathrm{g} / \mathrm{g}$ dry weight; $\mathrm{Cu} 21.8 \mu \mathrm{g} / \mathrm{g}$ dry weight; Cd $1.15 \mu \mathrm{g} / \mathrm{g}$ dry weight; Pb 2.31 $\mu \mathrm{g} / \mathrm{g}$ dry weight; Zn $898 \mu \mathrm{g} / \mathrm{g}$ dry weight) in the marsh clam tissue was recorded at station 4 which is near to the industrial area discharge. Whereas, those concentration were lower at Station 1 and Station 2, which located at the upstream and far from the industrial area discharge. On the other hand, the size of marsh clam does not significantly correlate to the concentration of selected trace metals. Level of selected metals in some the samples were exceeded the permissible limit provide by Malaysia Food Safety and Food Regulation 1985 especially marsh clam collected from station near to industrial area. Therefore, marsh clam collected for consumption near to industrial area need to be continuously monitor to prevent any acute effect on human health risk.
\end{abstract}

Keywords: Kelantan River, marsh clam, metals, permissible limit, human health risk

\begin{abstract}
Abstrak
Kerang seperti lokan (Polymesoda expansa) memperolehi makanan melalui proses penapisan zarah-zarah terampai di dalam air di sekeliling mereka. Banyak unsur-unsur elemen yang terperangkap di dalam badan mereka melalui tabiat makan ini termasuklah logam surih. Malangnya, lokan ini telah diambil oleh manusia dan dijadikan sebagai diet harian mereka. Disebabkan keupayaan lokan ini untuk menapis air, lokan telah digunakan untuk memantau tahap pencemaran logam berat di dalam persekitaran akuatik terutamanya di kawasan perindustrian. Oleh itu, kajian ini telah dijalankan di Sungai Kelantan berhampiran dengan kawasan perindustrian di Pengkalan Chepa, Kelantan, Malaysia. Sebanyak 80 lokan yang dikutip dari 4 kawasan
\end{abstract}


penyampelan untuk mewakili keadaan persekitaran yang berbeza. Keseluruhan tisu lembut lokan tersebut telah dikeluarkan dan dicerna dengan menggunakan kaedah Teflon bom dengan bantuan asid nitric suprapur. Kepekatan 6 logam telah ditentukan menggunakan spekrometri jisim gandingan aruhan plasma termasuk logam kromium, ferum, kuprum, cadmium, plumbum dan zink. Purata kepekatan logam yang dikaji (Cr $45.03 \mu \mathrm{g} / \mathrm{g}$ berat kering; Fe $1.28 \mu \mathrm{g} / \mathrm{g}$ berat kering; $\mathrm{Cu} 21.8 \mu \mathrm{g} / \mathrm{g}$ berat kering; Cd $1.15 \mu \mathrm{g} / \mathrm{g}$ berat kering; Pb $2.31 \mu \mathrm{g} / \mathrm{g}$ berat kering; $\mathrm{Zn} 898 \mu \mathrm{g} / \mathrm{g}$ berat kering) di dalam tisu lokan tersebut dicatatkan di stesen 4 yang terletak berhampiran dengan pelepasan sisa kawasan perindustrian. Kepekatan logam adalah lebih rendah di dalam lokan yang dikutip dari Stesen 1 dan Stesen 2 yang terletak di hulu sungai dan jauh daripada kawasan pelepasan sisa perindustrian. Selain itu, saiz lokan tidak mempengaruhi kadar kepekatan logam yang dikaji. Tahap kepekatan logam yang dikaji didapati melebihi had yang ditetapkan oleh Peraturan Makanan Malaysia 1985 terutamanya lokan yang dikutip dari stesen berhampiran kawasan perindustrian. Oleh itu, lokan berhampiran kawasan perindustrian perlu dipantau untuk mengelakkan apa-apa kesan akut kepada risiko kesihatan manusia.

Kata kunci: Sungai Kelantan, lokan, logam berat, had dibenarkan, risiko kesihatan manusia

\section{Introduction}

Heavy metals are a metallic chemical element that has a high density and are toxic or poisonous at low concentrations [1]. Living organisms need a certain amounts of some metals, including calcium, copper, iron, manganese, molybdenum, vanadium, strontium, and zinc in order to keep the metabolism activities inside the body functioning well $[2,3]$. However, heavy metals are also dangerous because they tend to bio-accumulate in the body of the organism [4].

Heavy metals have been recognized as a severe pollutant to the environment due to its hazardous effects. Industrial and agricultural activities were reported as the major sources of the accumulation of pollutants in the aquatic environment, including the sea $[5,6]$. These lethal wastes in the sea are highly probable to be accumulated in the sediments and marine organisms, including shellfish and consequently transfer to human beings through the food chain [7]. Shellfish are consumed by human beings and if accumulate large quantities of some metals from the water through daily consumption. It is important to determine the concentration of heavy metals in shellfish in order to evaluate the possible risk of the consumption for human health [8]. Shellfish contain quite great concentrations of carotenoids [9], low levels of fat and essential amino acids and also possess a relatively high content of vitamins and minerals [10]. For an example, bivalves have a much higher concentration of vitamins such as folate, cobalamin and minerals [10]. Today, it is generally accepted that fish and shellfish are important in a healthy and balanced human $\operatorname{diet}[11]$.

However, the evaluation of the risks and benefits of the consumption of these products has been particularly controversial. Even though, shellfish are very important human foods, but they exposed to chemicals in polluted and contaminated waters [12]. Toxicologists tend to relate shellfish as a major vector for toxic substances of metal trace elements and persistent organic pollutants [13]. The bioaccumulation of heavy metals by fish and shellfish make these food items can be a rich source of metal [14]. The interactions of heavy metals with usual elements form diet have an important role in acute and chronic toxicity [15].

Among the common approaches used to study environmental contamination, the use of bivalve mollusk as bioindicator species has proved to be a valuable and informative technique [16]. This approach has been particularly developed in temperate areas, whereas in sub-tropical and tropical areas the scarcity of available information makes the identification of species that could be used as suitable bio-indicators is difficult [17]. This study was conducted to evaluate the concentration of selected heavy metals accumulated in the seashell and beside to determine the size of seashells toward the concentration of metals in the seashell.

\section{Sample collection}

\section{Material and methods}

The seashells, ranged from 54 to $80.9 \mathrm{~mm}$ were collected in the mangrove area of the Kelantan River, located in Kota Bharu, Kelantan (Figure 1) during June 2013 in four different sampling stations. Sampling station 1 and 2 locate before industrial area, meanwhile station 3 and 4 locate near to industrial area. Various type of industries 
including food canning and manufacture of plastics. Sediment attached to the seashell was washed thoroughly by the in-situ water. All samples were stored in low temperature before the seashells were dissected in the laboratory.

\section{Sample analysis}

In the laboratory, the sample was washed with distilled water. Prior to analysis, the samples were classified, weighted, and the length measured using vernier caliper and all of the soft tissue were removed from their shells by using ceramic scalpel blades and then thoroughly rinsed to remove any extraneous impurities. The total weight and wet weight were recorded on the data sheet.

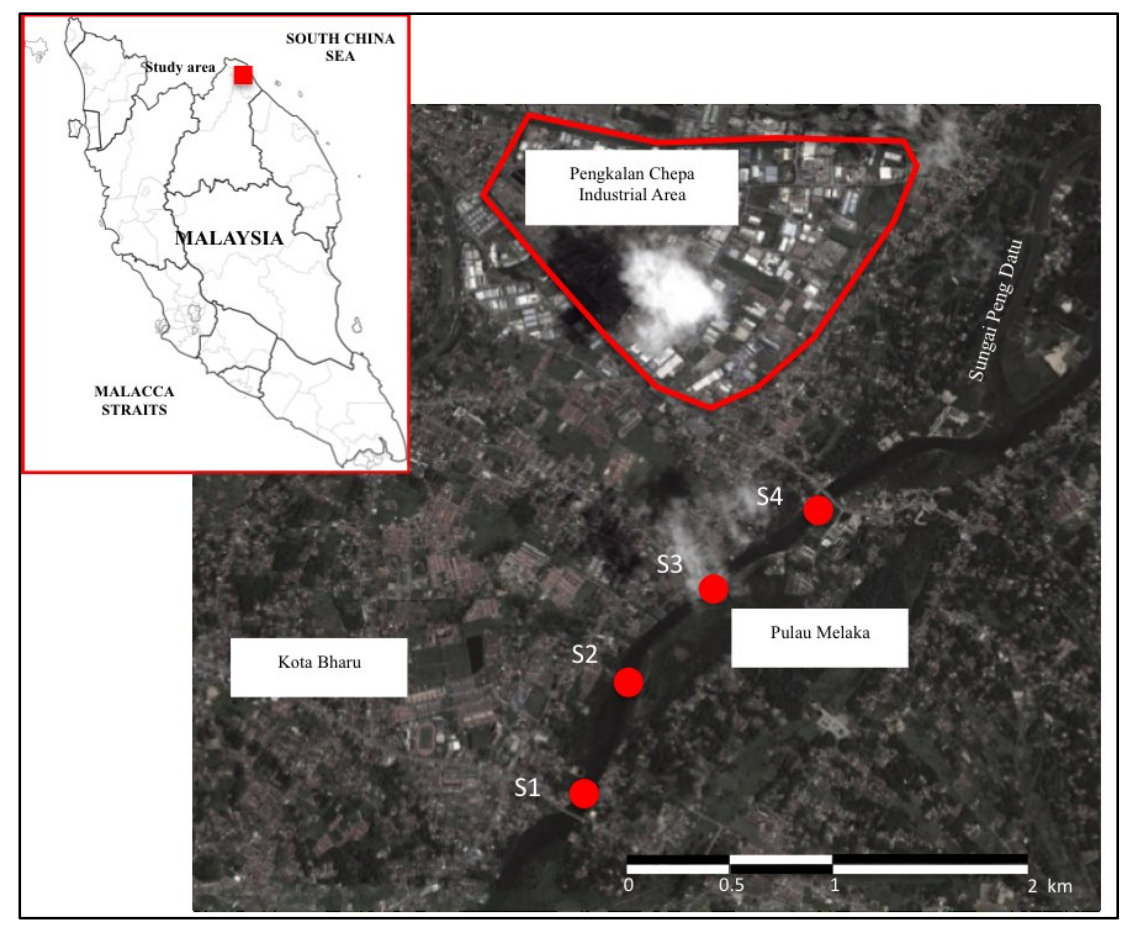

Figure 1. The sampling stations (Sungai Peng Datu, Kelantan) near to Kota Bharu city and Kampung Pulau Melaka

\section{Analytical method}

The soft tissue is weighted approximately to $0.05 \mathrm{~g}$ (dry sample) in Teflon digestion container. Suprapur nitric acid was added into each of the samples and let to predigest. Standard reagent, SRM1566 Oyster Tissue and blank were done simultaneously. After that, the container is covered and place in a stainless steel bomb, which is sealed with screw closure to avoid any acid leakage and store in the oven. The sample was heated in oven temperature for 7 hours at $100{ }^{\circ} \mathrm{C}$ in order to digest the sample completely. After cooling, the solution is transferred into a centrifuge tube diluted with deionized water to $10 \mathrm{~mL}$. The metals content, then measured by inductively-coupled plasma mass spectrometry (ICP-MS).

\section{Statistical analysis}

The statistical analysis, t-test of SPSS software is used to investigate the variation in trace elements concentration in the organisms and the sampling site. The levels of significance of the statistical analyses are set at 0.05 . 


\section{Average concentration of heavy metal in marsh clam}

\section{Results and Discussion}

Table 1 shows the overall results obtained from this study. Generally, cadmium $(\mathrm{Cd})$, lead $(\mathrm{Pb})$ and zinc $(\mathrm{Zn})$ relatively are higher in station 4 . Station 4 is the station that locates near to the end of the river and also near to the industrial area. However, concentration of chromium $(\mathrm{Cr})$ in station 2 is the lowest among all. Approaching to industrial area, the concentrations of metal seem to be increased. This shows the industrial area may affect the selected metal concentration inside the river and uptake by the clam.

Table 1. The average concentration of each metals in each station

\begin{tabular}{|c|c|c|c|c|c|c|}
\hline $\begin{array}{l}\text { Sample } \\
\text { ID }\end{array}$ & $\begin{array}{c}\mathbf{C r} \\
\left(\mu \mathrm{g} \mathrm{g}^{-1}\right)\end{array}$ & $\begin{array}{c}\mathbf{F e} \\
\left(\mu \mathrm{g} \mathrm{g}^{-1}\right)\end{array}$ & $\begin{array}{c}\mathbf{C u} \\
\left(\mu \mathbf{g ~ g}^{-1}\right)\end{array}$ & $\begin{array}{c}\mathbf{C d} \\
\left(\mu \mathbf{g ~ g}^{-1}\right)\end{array}$ & $\begin{array}{c}\mathbf{P b} \\
\left(\mu \mathbf{g ~ g}^{-1}\right)\end{array}$ & $\begin{array}{c}\mathbf{Z n} \\
\left(\mu \mathrm{g} \mathrm{g}^{-1}\right)\end{array}$ \\
\hline \multicolumn{7}{|c|}{ Station 1 (non-industrial area) } \\
\hline Average & $44.60 \pm 0.05$ & $0.50 \pm 0.05$ & $13.10 \pm 0.05$ & $0.54 \pm 0.05$ & $1.17 \pm 0.05$ & $323.65 \pm 0.05$ \\
\hline Std. Dev. & $32.06 \pm 0.05$ & $0.50 \pm 0.05$ & $9.72 \pm 0.05$ & $0.45 \pm 0.05$ & $0.61 \pm 0.05$ & $296.60 \pm 0.05$ \\
\hline \multicolumn{7}{|c|}{ Station 2 (non-industrial area) } \\
\hline Average & $25.05 \pm 0.05$ & $1.08 \pm 0.05$ & $17.89 \pm 0.05$ & $0.88 \pm 0.05$ & $1.89 \pm 0.05$ & $510.86 \pm 0.05$ \\
\hline Std. Dev. & $14.89 \pm 0.05$ & $0.61 \pm 0.05$ & $9.19 \pm 0.05$ & $0.34 \pm 0.05$ & $0.91 \pm 0.05$ & $197.50 \pm 0.05$ \\
\hline \multicolumn{7}{|c|}{ Station 3 (industrial area) } \\
\hline Average & $45.90 \pm 0.05$ & $1.04 \pm 0.05$ & $24.99 \pm 0.05$ & $0.91 \pm 0.05$ & $1.84 \pm 0.05$ & $752.00 \pm 0.05$ \\
\hline Std. Dev. & $62.24 \pm 0.05$ & $0.46 \pm 0.05$ & $7.34 \pm 0.05$ & $0.44 \pm 0.05$ & $0.66 \pm 0.05$ & $293.51 \pm 0.05$ \\
\hline \multicolumn{7}{|c|}{ Station 4 (industrial area) } \\
\hline Average & $45.03 \pm 0.05$ & $1.28 \pm 0.05$ & $21.81 \pm 0.05$ & $1.15 \pm 0.05$ & $2.31 \pm 0.05$ & $898.40 \pm 0.05$ \\
\hline Std. Dev. & $29.60 \pm 0.05$ & $0.46 \pm 0.05$ & $7.51 \pm 0.05$ & $0.68 \pm 0.05$ & $0.83 \pm 0.05$ & $390.06 \pm 0.05$ \\
\hline
\end{tabular}

Previous study shows the significant value that has been done in certain areas which may be affected by different physical and biological factor. Differences of value between the current study and previous study determined the toxicity of the area and may give harmful to human society and community through ingestion and consumption. Previous report shows there are four metals that have been studied along the Strait of Malacca. Several fishes have been catch and well preserved together with several cockles (Anadara granosa) [18]. However, there are only two same metals which previous report and this report have used include cadmium and lead. Previous study shows higher concentration of cadmium rather than in this study range from $25.1 \mu \mathrm{g} \mathrm{g}^{-1}$ to $47.0 \mu \mathrm{g} \mathrm{g}^{-1}$ [18]. This could be due to the fact that the habitat of Anadara granosa that are living at the bottom of the sea, nearly in the sediment where various kinds of hazardous and toxic substances are accumulated [19]. Lead in previous study showed much lower than the current study $\left(0.19 \mu \mathrm{g} \mathrm{g}^{-1}\right.$ to $\left.0.28 \mu \mathrm{g} \mathrm{g}^{-1}\right)$. Anadara granosa from Malacca's Straits was used as background comparison as there is no study that's been established around the Kelantan River.

A previous study in 1998, the report shows that the heavy metal concentrations of the bivalve Anadara (Senilia) senilis show a clearly distinct effect of size, small individuals having greater concentrations than large cockles [19]. Results should therefore be normalized for size before attempting any geographical or temporal comparison. In this study, statistically significant differences in metal concentrations of cockles between localities and years are explained by differences in the size distribution of the samples. Five types of metals studied in previous study show that than this study as the concentration is $309 \mu \mathrm{g} \mathrm{g}^{-1}$. In the previous study conduct during 1980 , the concentration in the cockles is much lower than in this research [20].

Generally, the levels in industrial area were higher compared to non-industrial area station. For example, the average concentration of $\mathrm{Cu}$ was $18 \mu \mathrm{g} \mathrm{g}^{-1}$ at Station 2 and $25 \mu \mathrm{g} \mathrm{g}^{-1}$ at Station 3, respectively. This clearly indicates the influence of aquatic environments [21] as well as surrounding human activities at a specific point of time may contribute to the accumulation of trace metals in marine organisms. Copper is one of the metals that is introduced 
into the aquatic environment through a number of natural methods. Copper is also a very useful substance for man. When these uses occur, some of that $\mathrm{Cu}$ is also presented in the aquatic environment [22]. In this study, the concentration of $\mathrm{Cu}$ in each sample is still below $30 \mu \mathrm{g} \mathrm{g}^{-1}$ and in safety level. Highest level of $\mathrm{Cu}$ was observed at station 4 . Thus, the accumulation of heavy metals in the aquatic environments has been associated with urban runoff, sewage treatment plants, industrial effluents and wastes, mining operations, boating activities, domestic garbage dumps and agricultural fungicide runoff [23].

On the other hand, the concentration of $\mathrm{Cr}$ is high and almost the same except for Station 2. The decrease of concentration may influence by the degradation of $\mathrm{Cr}$ by the biological process of marine organisms [24] or there are less human activity and production that contribute to the increase of $\mathrm{Cr}$ concentration. Although the graph shows the high concentration in both non-industrial area, yet it is considered as low. Besides, Cr has low toxicity and no adverse effects were observed at intakes of 1000 to $2000 \mu \mathrm{g} /$ day by human [25]. Due to the lack of adequate data, the EU Scientific Committee for Food (2003) has not suggested a Tolerable Upper Intake Level (UL) for Cr. The same conclusion was reported by the US Food and Nutrition Board and the UK Expert Group on Vitamins and Minerals [25].

For the iron $(\mathrm{Fe})$ in the clam samples, the highest percentage of concentration can be observed in samples at station 4. Similar with other metals, Fe also was carried through the stream and accumulates at the end of the river bank. Station 2 and 3 shows almost same value, probably due to the station located close to the industrial area. Surface and river runoff from the industrial area may contribute to the amount of the $\mathrm{Fe}$ present in the river.

The concentration pattern of cadmium $(\mathrm{Cd})$ is likely same as concentration of $\mathrm{Fe}$ and $\mathrm{Pb}$. The highest concentration of $\mathrm{Cd}$ exceeding safety level can be found in station 4 and lowest concentration of $\mathrm{Cd}$ can be found in station 1 . Although $\mathrm{Cd}$ is not widely used in human activities, but $\mathrm{Cd}$ is the essential component in the manufacture of solder, electrical supplies, batteries, phosphors in the production of televisions, anti-corrosive coatings for metals and bearing alloys [26]. However in this study, the $\mathrm{Cd}$ may come from natural resource as there are no specific industries utilized Cd present in the area of sampling located.

For lead metal $(\mathrm{Pb})$, the highest level was observed in an industrial area in station 4 and exceeding safety levels of human consumption while in lowest level can be found at Station 1. Station 4 has the highest concentration of $\mathrm{Pb}$ because of the accumulation of the heavy metal at the end of river bank [27]. It is because the industrial area may also contribute to the amount of the $\mathrm{Pb}$ concentration at Station $4 . \mathrm{Pb}$ is well known metal used in industry as paint, coating agent and storage of batteries. Although $\mathrm{Pb}$ is not harmful to human at low level, but if the amount takes more than the body can handle, the body will show some of the known symptoms of $\mathrm{Pb}$ poisoning such as headache, irritability, abnormal pain and various symptoms related to the nervous system.

The data about the zinc metal (Zn) show that all sampling stations exceed the safety level of human consumption, $150 \mu \mathrm{g} \mathrm{g}^{-1}$. Station 4 in industrial area shows the highest concentration of $\mathrm{Zn}$ in each sample. Excess level $\mathrm{Zn}$ has been accumulating at the end of the river and the source may come from the industrial area. The evidence in station 3 shows the concentration of zinc in higher than in non-industrial area (Station 1 and 2). Large doses of consuming zinc taken by mouth even for a short time can cause stomach cramps, nausea, and vomiting. Zinc is well known as metal that easily found dumped by villager in this river such as roof, barrel and component of car.

\section{Correlation of length and weight and the concentration of heavy metals}

From the tabular data of correlation between length of seashell and concentration of heavy metal, it was concluded that the heavy metal concentrations in the bivalve Polymesoda expansa are not related based on sample size (Figure 2 and 3). Small individuals having higher concentrations than large seashells and some small seashells also have lower concentration of metals than a large one or called as a growth dilution effect. The concentration of metals in samples is not directly proportional to the size, but regarding to the geographical or temporal comparison. In this study, statistically significant differences for concentration of metals in seashells between localities and years are clarified by differences in the size distribution of the samples. The areas itself give important in determining the status of metal toxicity in the current study. Moreover, the concentration levels of zinc, lead, cadmium and iron 
Ong et al: METALS CONTAMINATION USING Polymesoda expansa (MARSH CLAM) AS BIO-INDICATOR IN KELANTAN RIVER, MALAYSIA

shows that the highest concentration within the range of $60 \mathrm{~mm}$ to $70 \mathrm{~mm}$ of seashell's length, meanwhile for chromium and copper, the highest concentration can be found in the seashells with the range of $70 \mathrm{~mm}$ to $80 \mathrm{~mm}$.

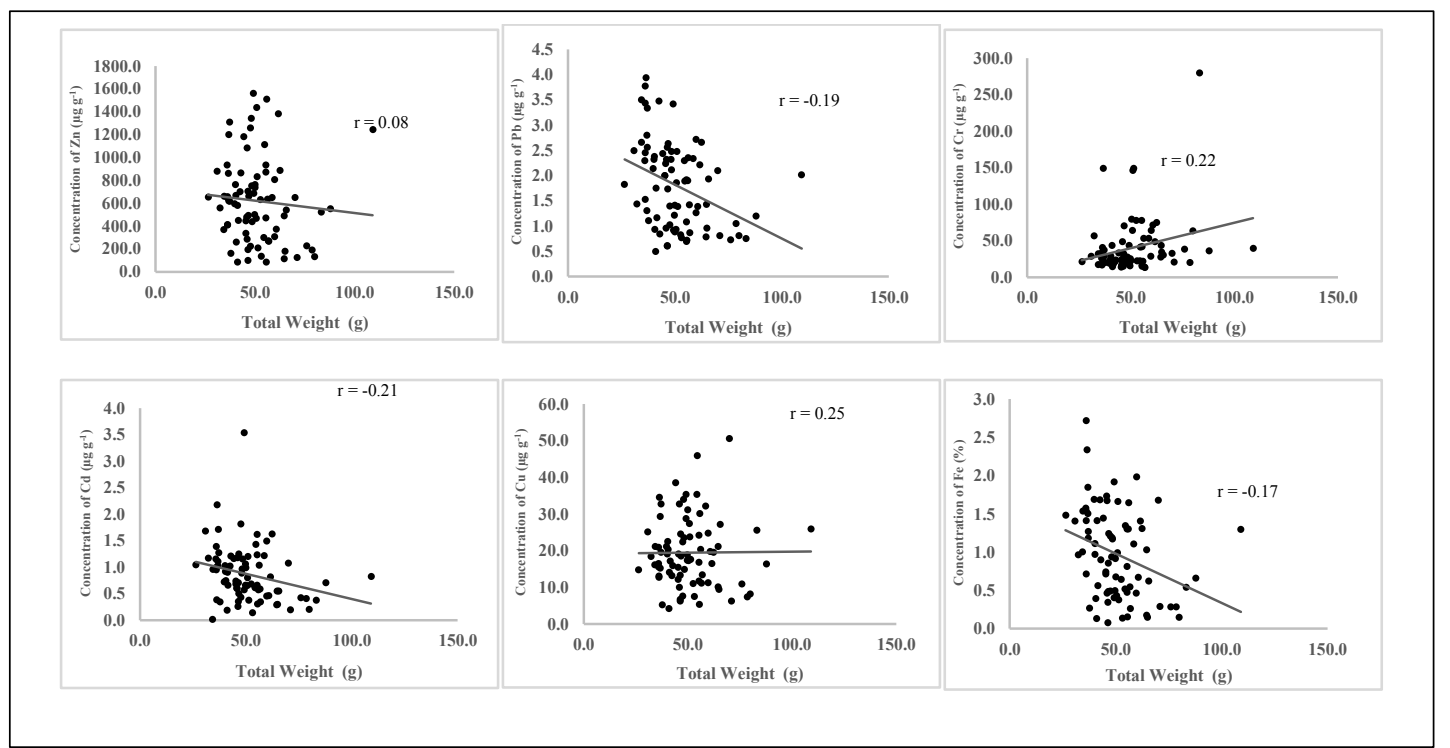

Figure 2. Correlation between weight of clam and the concentration of metals

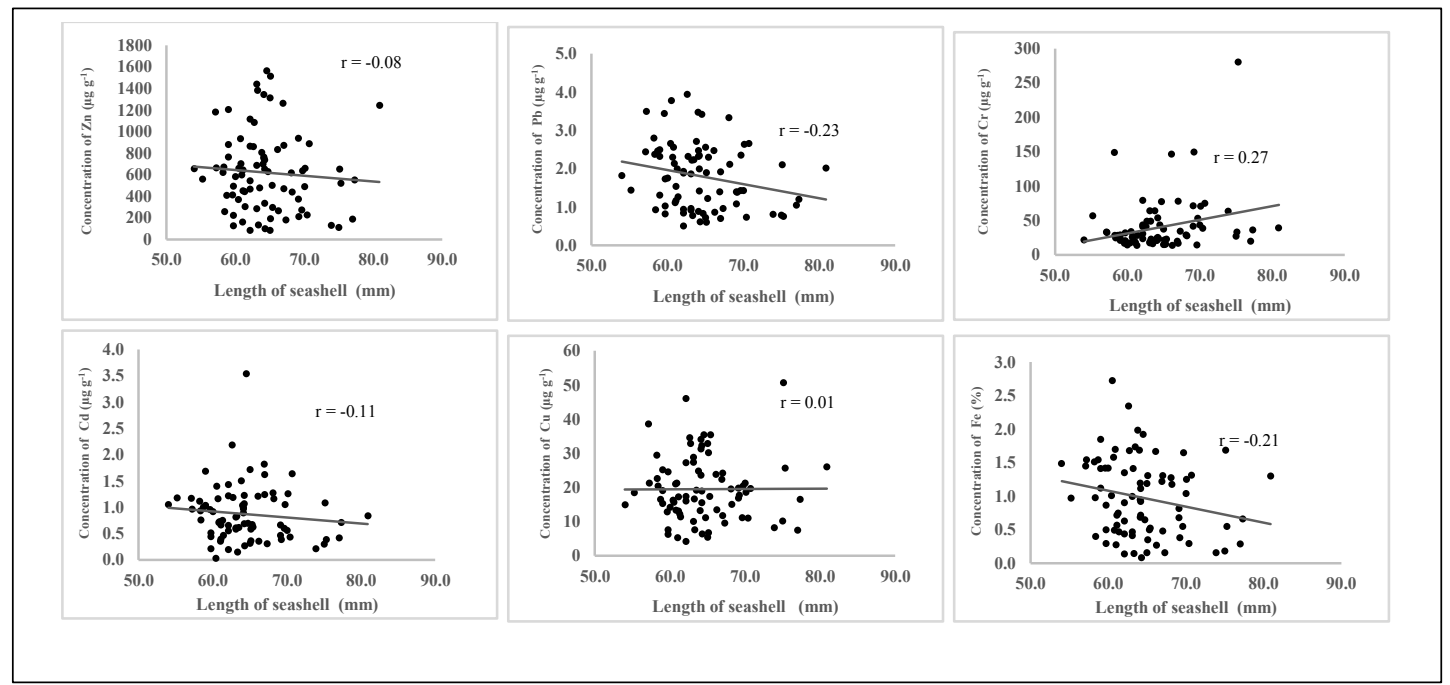

Figure 3. Correlation between length of clam and the concentration of metals

\section{Conclusion}

The concentration of metal in non-industrial and industrial area is most likely same and can determine that the industrial area use safe and work in accordance with the standards set. The metals in the river is not totally come from the industries but may come from rural activities. Vehicle and metal-based barrel dumping are also contribute to the increase of the concentration. The size of clam also play role in determining the concentration of heavy metal 
inside their body but limited to certain type of metals. From the correlation graph, some of metals are increase through size or length but some of metals are also decrease directly with size. However, there are some researchers claimed that the behavior of the seashell itself will 'consume' less if the area is really polluted. The gasping rate is decrease and less medium like water pass through the body. From the preliminary data obtained, the marsh clams at Kelantan River are still safe to be consumed. However, continuous consume the organism may lead to Zn poisoning due to the level of $\mathrm{Zn}$ is higher compare to standard values. Therefore, an intensive studies include water and sediment quality or other organism should be considered in order to obtain a better conclusion for metal pollution in Kelantan River.

\section{Acknowledgement}

This research was conducted with funding from the Ministry of Higher Education Malaysia (MOHE), under the Niche Area Research Grant Scheme (NRGS) project number 53131. The authors wish to express their gratitude to Oceanography and Biodiversity Laboratory, School of Marine and Environmental Sciences teams for their invaluable assistance and providing the facilities to carry out the research. We are grateful to our editors and referees for their invaluable comments that helped improve this manuscript.

\section{References}

1. Cid, B. P., Boia, C., Pombo, L., and Rebelo, E. (2001). Determination of trace metals in fish species of the Ria de Aveiro (Portugal) by electro thermal atomic absorption spectrometry. Food Chemistry, 75(1): 93 - 100.

2. Araya M, Pizarro F, Olivares M, Arredondo M, Gonzalez M. and Mendez, M. (2006). Understanding copper homeostasis in humans and copper effects on health. Biology Research, (39): $183-187$.

3. Harris, E. D. (2001). Copper homeostasis: the role of cellular transporters. Nutrition Revision, (59): 281 - 285.

4. Ryan, N. H. (2012). What You Should Know About Heavy Metals. Retrieve from: http://www.bewholebewell.com/articles/WhatYouShouldKnowAboutHeavyMetals.pdf. Date access 26 September 2013.

5. Freedman, B. (1989). Environmental Ecology. The impact of pollution and other stresses on ecosystem structure and function. London: Academic Press, (4): pp. 13 - 16.

6. Jordao, C. P., Pereira M.G., Bellato C. R., Pereira, J. L., and Matos, A. T. (2002). Assessment of water systems for contaminants from domestic and industrial sewages. Environmental Monitoring Assessment, (8): 33 - 36 .

7. Tuzen, M. (2003). Determination of heavy metals in fish samples of the middle Black Sea (Turkey) by graphite furnace atomic absorption spectrometry. Food Chemistry, (13): $17-21$.

8. Castro-González, M. I. and Méndez-Armenta, M. (2008). Heavy metals: implications associated to fish consumption. Environmental Toxicology and Pharmacology, (26): 263 - 271.

9. Britton, G., Liaaen-Jensen, S. and Pfander, H. (2009). Carotenoids: Nutrition and Health. Birkhauser Verlag. United States.

10. Holland, B., Brown, J. and Buss, D. H., (1993). Fish and Fish products. Royal Society of Chemistry and Ministry of Agriculture. Fisheries and Food, (2): $36-37$.

11. World Health Organization. (2003). Concise International Chemical Assessment Document 55. Polychlorinated biphrnyls: human health aspect. Retrieve from: http://www.inchem.org/documents/cicads/ cicads/ cicad55.htm\#10.0. Date access 26 September 2013.

12. Ikem, A. and Egiebor, N. O. (2005). Assessment of trace elements in canned fishes (Mackerel, Tuna, Salmon, Sardines and Herrings) marketed in Georgia and Alabama (United States of America). Journal of Food Composition and Analysis, (3): $34-37$.

13. Guerin, T., Chekri, R., Vastel, C., Sirot, V., Volatier, J., Leblanc, J. and Noel, L. (2011). Determination of 20 trace elements in fish and other seafood from the French market. Food Chemistry, (11): $12-16$.

14. Boscolo, R., Cacciatore, F., Berto, D. and Giani, M. (2007). Polychlorinated biphenyls in clams Tapes philippinarum cultured in the Venice Lagoon (Italy): Contamination levels and dietary exposure assessment. Food and Chemical Toxicology, (45): 1065 - 1075.

15. Leblanc J. C., Guerin T., Noel L., Calamassi-Tran G., Volatier J. C. and Verger P. (2005). Dietary exposure estimates of 18 elements from the $1^{\text {st }}$ French total diet study. Food Additives and Contaminants, (9): $22-25$.

16. Goldberg, E. D., Koide, M., Hodge, V., Flegal, A. R. and Martin, J. H. (1983). U. S. Mussel Watch: 1977-1978 results on trace metals and radionuclides. Estuarine, Coastal and Shelf Science, (12): $42-45$. 
Ong et al: METALS CONTAMINATION USING Polymesoda expansa (MARSH CLAM) AS BIO-INDICATOR IN KELANTAN RIVER, MALAYSIA

17. Phillips, D. J. (1991). Selected trace elements and the use of biomonitors in subtropical and tropical marine ecosystems. In Reviews of Environmental Contamination and Toxicology. Springer New York: pp. 105 - 129.

18. Alina, M., Azrina, A., Mohd Yunus, A. S., Mohd Zakiuddin, S., Mohd Izuan Effendi, H. and Muhammad Rizal, R. (2012). Heavy metals (mercury, arsenic, cadmium, plumbum) in selected marine fish and shellfish along the straits of Malacca. International Food Research Journal, (19): 135 - 140.

19. Joiris, C. R., Azokwu, M. I., Otchere, F. A. and Ali, I. B. (1998). Mercury in the bivalve Anadara (Senilia) senilis from Ghana and Nigeria. Science of the Total Environment, (224): 181 - 188.

20. Orren, M. J., Eagle, G. A., Hennig, H. F, Green, A. (1980). Variations in trace metal content of the mussel Choromytilus meridionalis (Kr.) with season and sex. Marine Pollution Bulletin, (11): 253 - 257.

21. Zhang, I. and Wong, M. H. (2007). Environmental mercury contamination in China: Sources and impacts. Environmental International, (33): $108-121$.

22. Lewis, A. G. (1995). Copper in water and aquatic environments, International Copper Association, LTD. New York, NY: pp. $1-2$.

23. Agency for Toxic Substance and Disease Register (2003). Toxicological profile for arsenic. US Department of Health and Humans Services, Public Health Human Services, Centres for Diseases Control, Atlanta.

24. Ehrlich H. L. (1996). How microbes influence mineral growth and dissolution: Chemical and biological control on mineral growth and dissolution kinetics, American chemical society meeting. Chemical Geology, (132): 5 9.

25. Scientific Committee on Food (2003). Tolerable upper intake level of trivalent chromium. SCF/CS/NUT/UPPLEV/67 Final. European Commission. Health \& Consumer Protection Directorate-General. Retrieve from http://europa.eu.int/comm/food/fs/sc/scf/out80_en.html, 2003. Date access 3 April 2014.

26. Hardy D. H., Myers J. and Stokes C. (2008) Heavy metals in North Carolina soils: Occurrence and significance. North Carolina Department of Agriculture and Consumer Services. Retrieve from: www.ncagr.gov/agronomi/. Date access on 28 March 2014.

27. Kamaruzzaman, B. Y., Shuhada, N. T., Akbar, B., Shahbudin, S., Jalal, K. C. A., Ong, M. C., Al-Barwani, S. M. and Goddard, J. S. (2011). Spatial concentrations of lead and copper in bottom sediments of Langkawi coastal area, Malaysia. Research Journal in Environmental Science, (5): 179 -186. 